Daimon. Revista Internacional de Filosofía, n ${ }^{\circ} 84,2021$ pp. 47-62

ISSN: 1130-0507 (papel) y 1989-4651 (electrónico)

http://dx.doi.org/10.6018/daimon.482011

Licencia Creative Commons Reconocimiento-NoComercial-SinObraDerivada 3.0 España (texto legal). Se pueden copiar, usar, difundir, transmitir y exponer públicamente, siempre que: i) se cite la autoría y la fuente original de su publicación (revista, editorial y URL de la obra); ii) no se usen para fines comerciales; iii) se mencione la existencia y especificaciones de esta licencia de uso.

\title{
Paving the road to hell: The Spanish word menas as a case study ${ }^{*}$
}

\section{Allanando el camino al infierno: la palabra española menas como caso de estudio}

\author{
DAVID BORDONABA-PLOU** \\ JOSÉ RAMÓN TORICES T**,**** $^{*}$
}

\begin{abstract}
Menas is a term that has attracted a great deal of attention on the political scene in Spain at present. Although the term had a neutral usage originally, being an acronym for unaccompanied foreign minors, it has recently evolved into a term with clear negative connotations. This article explores what kind of term menas is today. Specifically, we will examine whether menas is a slur or an ESTI, an ethnic/social term used as an insult. First, we point out the most defining characteristics of both types of terms. Then, using analyses on linguistic corpora, we show that menas exhibits the most defining characteristics of ESTIs. We end by discussing the possible evo-
\end{abstract}

Recibido: 31/05/2021. Aceptado: 02/07/2021.

* This publication resulted (in part) from research supported by CONICYT/FONDECYT/POSTDOCTORADO/ $N^{\circ}$ Proyecto 3180096, by MINECO under the grant FPI/BeS-2014-067584 and the research project PID2019-109764RB-I00, by the Regional Government of Andalusia under the research projects B-HUM459-UGR18 and P18-FR-2907, and by the University of Granada under a "Contrato Puente" fellowship and the excellence unit FiloLab-UGR UCE.PPP2017.04. We are grateful to the editors for making this special issue possible, and to Agustín Vicente and the two anonymous referees for their fruitful comments.

** David Bordonaba-Plou is a FONDECYT postdoctoral researcher at the Universidad de Valparaíso, Chile. Contact: davidbordonaba@gmail.com. His most recent publications are Bordonaba, D. (2021) "Metalinguistic negotiations and two senses of taste", Diametros, 18(67), 1-20, and Bordonaba, D. (2021), "Cognitive penetration and taste predicates: Making an exception to the tule", Filosofia Unisinos 22(1), 12-20.

*** José Ramón Torices is a postdoctoral researcher belonging to the excellence unit FiloLab-UGR and the research group Filosofía y Análisis (HUM-975). Contact: jrtorices@gmail.com. His most recent publications are Torices, J. R. (2021), "Understanding dogwhistle politics”, Theoria: An International Journal for Theory, History and Foundations of Science, DOI: 10.1387/theoria.22510, and D. Bordonaba, V. Fernández Castro and J. R. Torices (forthcoming), "The political turn: Analytic philosophy as philosophical activism", in D. Bordonaba, V. Fernández Castro and J. R. Torices (eds.), The Political Turn in Analytic Philosophy: Reflections on Social Injustice and Oppression, Berlin: De Gruyter.

**** The names of the two authors are in alphabetical order. Both authors have contributed equally to the paper. 
lution of the term, pointing out that, although the term presents the features related to ESTIs, there are two possible scenarios. On the one hand, the term may retain its neutral uses and thus remain an ESTI. On the other hand, the neutral uses may disappear, and thus the term may become a slur.

Keywords: menas, slurs, ESTIs, corpus linguistics, collocations, concordance de los TESNI. Acabamos discutiendo la posible evolución del término, señalando que, aunque el término tiene los rasgos de los TESNI, existen dos posibles escenarios. Por un lado, el término puede conservar sus usos neutros y de este modo seguir siendo un TESNI. Por otro lado, los usos neutros pueden desaparecer y así el término acabar convirtiéndose en un slur.

Palabras clave: menas, slurs, TESNIs, lingüística de corpus, colocaciones, concordancia

\section{Introduction}

Not long ago, most Spaniards did not know what the word mena ${ }^{1}$ meant. It was not an expression we heard in everyday conversations, nor was it used by the media. Most of us did not even know that such a word existed! MENA, a technical term that first appeared in the Boletín Oficial del Estado (BOE, "Official State Gazette") in 2009, is an acronym for Menores Extranjeros No Acompañados, "Unaccompanied Foreign Minors", that is, boys and girls under 18, non-European migrants, who are separated from their parents and are not in the care of any other adult in the host country. It was an expression neutrally used in legal and migration contexts to draw attention to the special vulnerability of these children. Nowadays, however, it is not easy to find a single Spaniard who does not know what the word means. A significant part of the racist discourse of Vox, the Spanish alt-right party, has revolved around this group. Vox's insistence on publicly vilifying them through fake news, hoaxes or hate speech, both in the media and on social networks, has succeeded in putting them at the centre of the political debate and thus popularising the term. ${ }^{2}$

The word mena has practically evolved from an unknown neutral acronym to a popular noun with negative connotations. Vox winning seats in the Andalusian parliament after the 2019 regional elections prompted several NGOs (for instance, Save the Children, SOSChildren's Village International or UNICEF) to warn on their websites and social networks about the dangers of using the expression mena to criminalise migrants children and teenagers. The term is currently used to associate being a Maghrebi male with being a criminal (thief, rapist, violent...).

Throughout this paper, we seek to understand this evolution and reflect on what kind of expression the word mena is. Specifically, we will analyse empirically whether we are dealing with a slur or an ESTI, i.e., an ethnic/social term used as an insult (see Castroviejo, Fraser and Vicente, 2020). Then, we will explain the conversational dynamics that have led to this shift from neutral to offensive usage. Our aim is thus twofold: first, to understand what kind of expression the term mena has become, and second, to draw some generalisations about how an expression evolves from having only a neutral use to an offensive or simultaneously

1 We follow the extended practice in cross-linguistic studies of italicizing the original expression and using quotation marks for the translation of that expression.

2 See "La vida visible de las palabras: un análisis del concepto "mena" y su uso en redes" (2019), by Isabel Martín Piñeiro for El Salto Diario: https://www.elsaltodiario.com/comunicacion/Analisis-palabra-mena-racismo. 
neutral and offensive use. Concerning the first aim, our thesis is that the expression mena is currently used both neutrally and offensively, with a tendency towards the disappearance of the first type of use. The word mena is, thus, an ESTI that may end up becoming a slur. As for the second aim, our thesis is that the systematic appearance of a neutral expression (with descriptive meaning) together with negative evaluative expressions ends up turning the neutral expression into an expression with a negative use (with expressive meaning) which may lose its neutral use, becoming a slur, or keep it together with the offensive one, becoming an ESTI.

To fulfill these two aims we will compile a corpus of Spanish tweets containing the term menas. Then, we will perform some quantitative and qualitative analysis to show to what extent menas is an ESTI. Specifically, we will perform a collocation analysis, i.e., we will determine which words most often co-occur with menas, and a concordance analysis, i.e., we will inspect the term menas in context. Through these two analyses, we will obtain the empirical evidence necessary to determine the extent to which menas presents the features that are characteristically associated with ESTIs.

The paper is divided as follows. Section 2 characterises slurs, emphasizing the most salient features of this set of terms. Section 3 similarly characterises ESTIs. Section 4 explains the methods and materials used in the study. Section 5 presents the collocation and the concordance analyses. Finally, Section 6 assesses the results of the analyses, discussing the status of the term and its possible future evolution and drawing some generalisations to shed some light on the process by which a neutral term can end up becoming an offensive one.

\section{Words That Hurt I: Characterising Slurs}

A slur is an evaluative expression used to derogate members of a particular social group on the grounds of race, gender, social status, sexual orientation or religion, among other social identities (see, e.g., Hom, 2008; Anderson and Lepore, 2013; Camp, 2013; Croom, 2013, 2015; Jeshion, 2013; Blakemore, 2015; Cepollaro, 2015). They are a particularly abusive kind of expression because they have the potential to "harm and degrade their targets, making them feel humiliated, dehumanised, disempowered, and silenced" (Popa-Wyatt and Wyatt, 2018, 2880). It is widely agreed that there is a non-pejorative or neutral counterpart used for picking out the same set of individuals for each slur. According to the mainstream view (see, e.g., Croom, 2015 and Falbo, 2021 for exceptions), the slur "dago", for instance, has roughly the same descriptive content, the same truth conditions, as the expressions "Spaniard", "Italian" or "Portuguese," but "dago" also implies that they are, qua Spaniard, Italian or Portuguese, bad people. Some characteristic features of slurs, following Bolinger (2017), include the following: ${ }^{3}$

- Offensive Autonomy - slurs are offensive even when the speaker does not intend the use to be derogatory.

- Embedding Failure - the derogatoriness of slurs projects out of various forms of embedding, including indirect reports, negations, and mentions.

- Perspective Dependence-use of a slur is taken to indicate that the speaker holds derogatory attitudes.

3 These features are also true for slurs in (European) Spanish. 
- Offensive Variation - not all slurs, even if co-referential, appear to be equally offensive.

- Insulation-despite all the above, slurring terms can occasionally occur inoffensively, which is true even of particularly strong ones. (Bolinger, 2017, 439)

Let's say a little more about these properties of slurs. First, the power of degradation, humiliation and offence towards a slur's target is bigger than that of an individual insult. According to Camp $(2013,330)$, they "are among the most rhetorically powerful and insidious expressions in a language", and their harmfulness does not depend on the speaker's attitudes or intentions. In other words, slurs are conventionally derogative (Cepollaro, 2015, 37). The speaker's not being a racist does not remove the harmful and racist ingredient from her racist slurring utterance. In fact, it is quite the opposite. Except on rare occasions, the use of a racist slurring word makes the speaker a racist.

Second, unlike other offensive expressions such as "jerk", "bastard" or "asshole", slurs" offensiveness preserves when embedded under negation, questions, conditional antecedents, or modals (see, e.g., Hom, 2008, 435; Cepollaro, 2015, 37). Let's illustrate this idea with some examples:

(1) José is an asshole.

(2) José is not an asshole.

(3) José is a dago.

(4) José is not a dago.

By negating (1), the speaker rejects that the property being an asshole can be predicated of José. "Asshole" applies to him by virtue of his attributes. Thus, when the speaker denies that José is an asshole, she denies that José possesses those attributes. By negating (3), however, the speaker rejects that the property being a dago can be predicated of José, but, unlike with "asshole", "dago" is still an offensive way of referring to a certain social group even when José does not belong to it.

Third, the use of a slur is not only an unfair way of presenting a specific social group; it is also, following Nunberg (2018), a way of exhibiting and building camaraderie among the users of such expressions. The display of camaraderie is crucial in explaining one of the social functions of slurs because it explains why many of the users of these expressions employ them, especially in contexts where there are non-targeted members present. As Bolinger $(2017,447)$ notes, when a speaker chooses from among two expressions $\alpha$ and $\beta$, the one that is associated with a certain negative attitude $\phi$ towards a particular social group rather than choosing the one that is not, that choice is a signal that the speaker endorses $\phi$.

Fourth, the derogatory potential of a slur varies from one to another. While all slurs infringe upon the dignity of the social group they attack, they do not all humiliate or degrade in the same way. As Hom (2008) notes, some are more damaging than others. The meaning and harmful potential of a slur may vary over time along with the social norms and values that underpin that meaning and harmful potential. Expressions that were once offensive may no longer be so today. 
Finally, using a slur can have a high social cost for the speaker. There are very few contexts if any (see Anderson and Lepore, 2013 on this point), in which a slur can be used without being perceived as inappropriate and derogative. As Hom points out, "[u]ses of epithets are subject to strict social constraints, if not outright forbidden" (Hom, 2008, 427). The use of slurs is, thus, practically a taboo for members of the non-targeted group beyond a few special contexts (direct quotations, dictionary entries, or memos advising against the use of offensive terms).

\section{Words That Hurt II: Characterising ESTIs}

Slurs, as we have seen, are expressions whose use is offensive by default. In Spanish, as in other languages, there are plenty of slurs. ${ }^{4}$ Some examples of Spanish slurring words are sudaca (for Latin Americans), guiri (for white tourists from Northern Europe and America), or gabacho (for Frenchs). However, slurs are not the only type of expression used to derogate certain social groups. Some expressions can be used descriptively to refer to certain social groups and can also be used offensively. Gitano (for Romani) or moro (for people from North Africa) seem to fit into this category. Castroviejo, Fraser and Vicente (2020) have called such expressions "ethnic/social terms used as insults" (ESTIs, for short). In Spanish, ESTIs can be preceded by an indefinite (i-ESTI, for short) or not (w-ESTI, for short). An i-ESTI is primarily offensive, while an w-ESTI can be used neutrally (n-ESTI, for short) or offensively (o-ESTI, for short).

The most prominent features of ESTIs, largely following Castroviejo, Fraser and Vicente (2020), are:

- Context-dependent Offensiveness-w-ESTIs' offensiveness is highly dependent on contextual singularities, while when it is an i-ESTI its offensiveness is autonomous.

- Stereotype-based Offensiveness - i-ESTIs' application hinges on the individual insulted meeting the stereotypes associated with the target group, not on that individual belonging to it.

- Mixed Embedding Behaviour-i-ESTIs project out of various forms of embedding. w-ESTIs do not project when embedded.

- Perspective Dependence--generally speaking, using an i-ESTI or an o-ESTI signals that the speaker holds derogatory attitudes towards the target group.

- Offensive Variation -ESTIs, when used offensively (whether an i-ESTI or an o-ESTI) do not appear to be equally offensive. Their offensiveness depends on how negative the stereotypes associated with the target group are.

Unlike slurs, ESTIs are often used both neutrally to refer to a group based on their ethnicity or background (n-ESTI) and as an insult (i-ESTI) to refer to people who do not belong to the targeted group. Although one of the most defining features of slurs is that they derogate individuals by group membership, several authors have argued that slurs can be used neutrally and refer offensively to out-group people. First, Zeman (2021) argues that the Romanian slur tigan can be used neutrally to identify as being of Roma ethnicity. However, this case would not constitute a counterexample against the thesis that ESTIs, unlike slurs, can be used neutrally

4 In what follows, we focus on expressions used in (European) Spanish. 
by members of the non-targeted group. According to Zeman $(2021,5)$, the neutral use of tigan is only allowed for the Romanian Romani population. ESTIs, as mentioned above, can be used neutrally by members of the non-targeted group and in everyday contexts, not only in some exceptional contexts, as is the case with slurs. Second, according to Jeshion $(2013,324)$, "slurs' extended uses" involve the application of slurs to people who are not members of the targeted group. However, although possible, we believe that these cases represent a small fraction. On the contrary, ESTIs are often applied offensively to people outside the group, which may be just as common as cases where they are not, which vindicates the asymmetry noted.

Another crucial difference is that, unlike slurs, whether an ESTI is used offensively depends entirely on the speaker exploiting the associated stereotype..$^{5}$ As Castroviejo, Fraser and Vicente note, ESTIs are strongly linked to stereotypes. This link is most clear in their application to individuals who do not belong to the target group. The fact that an ESTI, when used derogatorily, can be applied to people who do not belong to the target group shows, in our view, that users of an ESTI must be aware of the stereotypes that characterise it in a way that they do not have to be when using a slur. In other words, in the case of ESTIs, the most crucial factor in determining their conditions of application is not group membership, as in the case of slurs, but the compliance with the stereotypes attributed to the target group.

ESTIs have both neutral and offensive uses. At least in (European) Spanish, i-ESTIs are usually offensive. But, as we have seen, there are also o-ESTIs. This has consequences for the behaviour of ESTIs when they are embedded. Appearances of an i-ESTI scope out just like slurs. w-ESTIs do not project even when offensive. Let's look at some examples:

(5) Juan es gitano. (“Juan is Romani" = $n$-ESTI/o-ESTI)

(6) Juan no es gitano. ("Juan is not Romani" = $n$-ESTI/o-ESTI)

(7) ¿Juan es gitano? ("Is Juan Romani?" = n-ESTI/o-ESTI)

(8) Juan es un gitano. ("Juan is (a) Romani" = $i$-ESTI)

(9) Juan no es un gitano. ("Juan is not (a) Romani" = $i$-ESTI)

(10) ¿Juan es un gitano? ("Is Juan (a) Romani?" = $i$-ESTI)

(5-7) are sentences in which gitano can be $n$-ESTI or o-ESTI but knowing this is necessary to know some particularities of the context. In any case, it seems that (5-7) in neither of their two possible interpretations, $n$-ESTI or $o$-ESTI, projects out. o-ESTIs neutralises the stereotypes when embedded. That it does not project out when the content is neutral is to be expected, that it does not project out when the content is offensive distances o-ESTIs from slurs. In (8-10), however, the offensive content does project out. When the ESTI is preceded by the indefinite, the speaker still exploits the stereotypes attached to the i-ESTI even though it is embedded under the interrogative. i-ESTIs scope the stereotype out, even if it is embedded.

ESTIs, when used to insult, constitute a signal of the speaker's negative attitude towards the target group. However, it should be noted that an ESTI can also be used to express positive attitudes towards the target group and not only by members thereof (see Castro-

5 According to Jeshion $(2013,324)$, in "slurs' extended uses", the racial (or gender) component still plays a role. However, Tirrell (1999) defends that the stereotype is crucial for the slur to be offensive in these types of uses. It is not our aim to offer arguments for or against stereotype semantics of slurs, but to point out that the offensiveness of an ESTI depends more directly on whether the speaker exploits the stereotypes associated. 
viejo, Fraser and Vicente, 2020, 11, n. 14). Some people may associate positive stereotypes with the target group. For these people, saying something like $X$ es un gitano, " $\mathrm{X}$ is (a) Roma", means that $\mathrm{X}$ is someone who has certain positive qualities (loyalty, freedomloving...) precisely because $\mathrm{X}$ belongs to that group. Therefore, unlike slurs, the very use of the term by members of the non-targeted group is not by default a sign of the speaker's negative attitude. In addition, it is valuable to note that sometimes the same stereotype can be perceived as positive or negative by members of the non-targeted group. For example, saying that the Roma have music "in their blood" can mean something positive (they are skilled musicians) or something negative (they prefer to be idle rather than work hard). In any case, whether it is used to insult or to praise, the use is not neutral but evaluative, and hence perspective-dependent.

Finally, how offensive an ESTI is will depend on the associated stereotypes. The associated stereotypes are not equally harmful. For example, the stereotype that Germans are humourless is negative but less negative than the stereotype that Roma are fraudsters. Both stereotypes are negative, but to different degrees: it is more harmful to be perceived as a fraudster than as someone lacking a sense of humour.

\section{Methods and Materials}

In the last years, several authors have advocated the use of linguistic corpora to investigate issues in the philosophy of language (Bluhm, 2013, 2016; Hansen, 2015; Hansen \& Chemla, 2015; Hansen et al., 2019; Caton, 2020; Hinton, 2020; Tallant \& Andow, 2020). Although it is not the most widespread methodology, it has certain advantages that make it desirable over other options. First, linguistic corpora are unbiased data sets. As Bluhm (2013, p. 12) puts it, corpora "data are, by and large, unfiltered".

Second, when using linguistic corpora, we analyze the frequencies of terms or the frequencies of the expressions that typically co-occur with them. However, corpora also provide the broader contexts in which the words appear. A detailed analysis of this broader context may discover new features about the phenomenon we are studying.

Third, computer processing allows for automatic and more in-depth analyses. RStudio (see Desagulier, 2017; Gries, 2017) and \#Lancsbox ${ }^{6}$ are available options for the analyses. However, since the corpus language is Spanish, we chose Sketch Engine ${ }^{7}$ because of the ease with which it processes non-English languages.

Fourth, the amount of evidence considered is high. Given the specificity of the subject studied in this work, we have not used general corpora, but a "specialized or special corpora" (Pearson, 1998, 51; Bowker \& Pearson, 2002, 48). The size of these corpora is significantly smaller. Even so, our corpus reached a size more than sufficient to carry out a representative and in-depth analysis on the subject studied. Specifically, the corpus has 631.418 words and 24.817 occurrences of the term menas.

We compiled our special corpus mining Spanish tweets (and their answers) in which the word menas appears. The tweets compounding the corpus were mined from three different

6 http://corpora.lancs.ac.uk/lancsbox/.

7 https://www.sketchengine.eu/. 
times: i) September 14, 2020 to September 28, 2020; ii) October 17, 2020 to November 7, 2020; and iii) March 17, 2021 to April 3, 2021. First, we focus on two specific moments, the declaration of Díaz Ayuso, president of the Community of Madrid, Spain, on September 21,2020 , and the riots that occurred in different Spanish cities due to the COVID measures on October 31, 2020. ${ }^{8}$ Specifically, we extracted the tweets from the week before and after both events, i.e., two periods of fifteen days each. We chose the former incident because Díaz Ayuso used the term menas explicitly in her statement. ${ }^{9}$ Therefore, we expected that there would be many tweets mentioning the term. The latter event is not related to menas. However, being a time of high social tension, we anticipated much movement on Twitter. As we expected, the term appeared in many tweets. Then, we mined tweets from a time (from March 17, 2021, to April 03, 2021) when no significant political or social event occurred to make the corpus more balanced.

To assess the status of the term menas, we carry out two analyses: a collocation and a concordance analysis. First, a collocation is "the tendency of words to be biased in the way they co-occur" (Hunston, 2002, 68). That is, collocates are words "that occur frequently within the neighborhood of another word, normally more often than we would expect the two words to appear together because of chance" (Baker, Gabrielatos and McEnery, 2013, 36). The collocation analysis will allow us to see which terms (neutral and pejorative) usually accompany menas, and how often each of them appears typically. Second, a concordance analysis consists in obtaining a "list of all of the occurrences of a particular search term in a corpus, presented within the context that they occur in" (Baker, 2006, 71). In a nutshell, a KWIC (for key words in context) analysis serves to visualize all occurrences of a search term in a corpus with its context. In this work, the KWIC analysis will help us find examples to test whether menas presents the features that are characteristically associated with ESTIs.

Before presenting the analyses mentioned above, it should be noted that the analyses carried out in the present study are radically different from the linguistic tests reported in Castroviejo, Fraser and Vicente (2020). According to the authors, these linguistic tests make it possible to differentiate which terms are ESTIs. First, we should begin by saying that the corpus evidence allows us to conclude that the term menas passes three of the five tests: i) "the emphatic Spanish indefinite" (see Castroviejo, Fraser and Vicente, 2020, 7-10), in examples like Lacoste y iPhone. Estos no roban en mercadillos, faltaría más. Son unos menas muy monos, "Lacoste and iPhone. They don't rob at flea markets, of course. They are cute little menas"; ii) "degree modification" (see Castroviejo, Fraser, and Vicente, 2020, 11-12), in examples like Son unos MENAS de cojones!, "They are MENAS as shit!"; and iii) "the auténtico environment" (see Castroviejo, Fraser and Vicente, 2020, 12-13), since we find examples like No hay que leer nada, solo ver las imágenes. Auténticos menas, "No need to read anything, just look at the images. Real menas".

Concerning the other two tests, menas may pass one of them, "verbless exclamatives" (see Castroviejo, Fraser, and Vicente, 2020, 7),${ }^{10}$ while it is impossible to know whether it

8 https://www.elmundo.es/espana/2020/10/31/5f9d33bb21efa099058b4638.html.

9 https://www.publico.es/tremending/2020/09/21/isabel-diaz-le-pen-ayuso-cuela-un-mensaje-relacionando-lacovid-con-delincuencia-okupas-y-menores-extranjeros/.

10 Consider the following example: Por qué todos los pibes de 13 años se visten de menas, "Why do all 13-yearold boys dress like menas". Given this tweet, we believe that the following example sounds OK: Todos los pibes 
passes the other, "N1 of an N2 construction" (see Castroviejo, Fraser, and Vicente, 2020, 6), because the test refers to features more directly related to spoken language, something impossible to check in our case.

Even leaving this aside, there are reasons not to apply such linguistic tests in the analyses. First, the intuitions we have regarding some of the tests do not coincide with those of the authors. ${ }^{11}$ Second, since ESTIs are terms where context plays an important role and where associated stereotypes play a differential role, we prefer to use corpus methods such as concordance and collocation analysis to explore these two issues. The former allows us to observe the term in context, while the latter gives us a set of terms associated with menas, allowing us to extract the associated stereotypes.

\section{Analyses}

As we have seen in Section 3, ESTIs have five distinctive features. In this section, we will expose the outcomes of the analyses to see if the term menas exhibits these five features and thus if it is more like an ESTI than a slur. First, context-dependent offensiveness refers to the idea that ESTIs, unlike slurs, are frequently used both neutrally and offensively. Specifically, the offensiveness of w-ESTIs depends on the context, while the offensiveness of i-ESTIs, when applied to people outside the target group, does not. Consider the following examples:

(11) Criminalizar y señalar a MENAS, por ejemplo desde grupos políticos es violencia y racismo. "Criminalizing and pointing to MENAS, for example from political groups, is violence and racism."

(12) Y sí, estamos hasta la polla de los inmigrantes ilegales y menas que sólo crean problemas. "And yes, we are sick to death of illegal immigrants and menas who only create problems."

(13) Pues los que destrozan no destrozan porque le vaya a faltar el pan, destrozan porque son unos menas hijos de la gran puta. "Well, those who vandalize do not vandalize because they are going to lack bread, they vandalize because they are menas sons of bitches."

(14) Estos no roban en mercadillos, faltaría más. Son unos menas muy monos. "They don't steal from flea markets, of course. They are cute little menas."

As shown by the examples, cases where menas is used as an i-ESTI are pejorative, whereas when it is used as a w-ESTI can be offensive or neutral. A close examination of the cases where menas is an i-ESTI reveals that the contexts are predominantly negative. Of the 19 copular construction cases (i.e., copula + indefinite article + menas), there are 17 cases where the context is negative. On the contrary, when menas is used as a w-ESTI, we find negative contexts, but also a lot of neutral ones where the term is related with the idea that menas are children.

de 13 años se visten de menas. Mira qué se ha puesto hoy Manolito. ¡Todo un mena, tu primo!, "All 13-year-old boys dress like menas. Look what Manolito is wearing today. A total mena, your cousin!".

11 In our view, the $\mathrm{N}_{1}$ of $\mathrm{N}_{2}$ construction, for instance, works well with the ESTI gitano, but does not sound very idiomatic with the ESTI portera. Similarly, with some slurs, the construction $\mathrm{N}_{1}$ of $\mathrm{N}_{2}$ sounds idiomatic to us: la puta de tu hermana "the bitch of your sister", or el maricón de tu hermano "the fagot of your brother". 
Second, stereotype-based offensiveness alludes to the idea that the application of an ESTI (whether an i-ESTI or a w-ESTI) depends on the insulted person meeting the stereotypes usually associated with the target group, and not on the fact that the person belongs to the group. Consider the following cases:

(15) Ya no hay jóvenes en este país, solo menas. Mi sobrino de 14 años, lleva ese pelado, ese look, ... será un mena? "There are no young people in this country anymore, only menas. My 14-year-old nephew wears that haircut, that look, ... is he a mena?"

(16) Parecen todos fotocopias. ¿Solo existe ese corte de pelo? Cuidao que mañana les llaman menas. "They all look like photocopies. Is there only one haircut? Be careful, tomorrow people will call them menas."

(17) Son menas pagados, el fenotipo es magrebí. "They are paid menas, the phenotype is Maghrebi."

As can be seen, applying the concept in all the examples does not depend on whether the individual in question is an unaccompanied foreign minor, but on whether he or she is wearing a particular haircut or is a Maghrebi. Ultimately, the offensiveness of menas depends on whether the individual to whom the concept is applied meets the stereotypes generally associated with the term.

Third, mixed embedding behaviour says that w-ESTIs do not project out of various forms of embedding, while i-ESTIs do project. Consider the following examples:

(18) Es lo que tiene el racismo, que veis lo que quereis... Como sabeis que son menas? "That's the thing about racism, you see what you want to see... How do you know they are menas?"

(19) Veo a muchas chicas blancas en los videos, esas no son menas, esta claro que algo hemos hecho muy mal con esta juventud. "I see a lot of white girls in the videos, those are not menas, it is clear that we have done something very wrong with this youth."

(20) los troyanos que nuestras queridas élites han introducido en nuestras sociedades para fomentar el caos y el miedo, MENAS. ¿Tenéis pruebas para demostrar que son unos menas? "the Trojans that our beloved elites have introduced into our societies to foment chaos and fear, MENAS. Do you have evidence to prove that they are menas?"

(21) Esperemos que no hayan sido unos menas, que entonces se te cae todo el argumento. "Let's hope they weren't menas, then the whole argument falls apart.

As the examples show, although in the two examples where menas is used as an i-ESTI it does seem that the term projects out, the intuitions regarding the examples where menas is used as a w-ESTI are not clear. It could be that the term does not project out in the first example, but projects in the second, but it is not entirely clear for us.

Fourth, perspective dependence conveys the idea that ESTIs signal that the speaker holds derogatory attitudes towards the target group. Examining the different collocates of menas, 
we can find both neutral and offensive uses. Among the most frequent modifiers of menas (see Table 1), we find the neutral collocate menores "minors", with a Log Dice ${ }^{12}$ of 8.94. However, we also find pejorative collocates. For example: i) putos, "fucking" (Log Dice: 10.57); ii) malditos, "damned" (Log Dice: 8.66); iii) violadores, "rapist" (Log Dice: 8.51); and iv) violentos, "violent" (Log Dice: 8.43).

\begin{tabular}{|c|c|}
\hline Collocate & Log Dice \\
\hline putos (“fucking") & 10.57 \\
\hline marroquíes ("Moroccan") & 9.41 \\
\hline pobres ("poor") & 9.31 \\
\hline nazis ("nazis") & 9.25 \\
\hline menores ("minors") & 8.94 \\
\hline morenos ("dark") & 8.85 \\
\hline malditos (“damned") & 8.66 \\
\hline violadores ("rapist") & 8.51 \\
\hline musulmanes (“muslim”) & 8.46 \\
\hline violentos ("violent") & 8.43 \\
\hline
\end{tabular}

Table 1. Top ten modifiers of menas

Regarding the construction menas son, "menas are", we find neutral and pejorative collocates (see Table 2). Among the neutral collocates, we find: i) menores, "minors" (LogDice: 11.41); ii) niños, "children" (Log Dice: 10.71); and iii) personas, "people" (Log Dice: 10.45). However, we also find the pejorative collocate problema, "problem" (Log Dice: 11.43$)$.

\begin{tabular}{|c|c|}
\hline Collocate & Log Dice \\
\hline problema (“problem") & 11.43 \\
\hline menores (“minors") & 11.41 \\
\hline niños ("children") & 10.71 \\
\hline ultraderecha ("far right") & 10.53 \\
\hline personas ("people") & 10.45 \\
\hline
\end{tabular}

Table 2. Most frequent collocates of menas son, "menas are"

Regarding the verbs to which menas appear as subject, we also find neutral and pejorative collocates (see Table 3). Among the neutral ones, the following can be noted: i) nacer, "be born" (Log Dice: 10.3); ii) tener, "have" (Log Dice: 9.7); iii) votar, "vote" (Log Dice: 8.98); and iv) decir, "say" (Log Dice: 8.89). However, we also find a lot of pejorative collocates among the most frequent ones: i) robar, "steal" (Log Dice: 10.98); ii) saquear, "loot"

12 Log Dice is a statistical measure that expresses "the tendency of two words to co-occur relative to the frequency of these words in the corpus". It is a "standardized measure operating on a scale with a fixed maximum value of 14" (Gablasova, Brezina and McEnery, 2017, 164). 
(Log Dice: 10.77); iii) apuñalar, "stab" (Log Dice: 10.41); iv) delinquir, "commit crime" (Log Dice: 9.53); and v) asaltar, "rob" (Log Dice: 9.25).

\begin{tabular}{|c|c|}
\hline Collocate & Log Dice \\
\hline robar ("steal") & 10.98 \\
\hline saquear ("loot") & 10.77 \\
\hline apuñalar ("stab") & 10.41 \\
\hline nacer ("be born”) & 10.3 \\
\hline tener ("have") & 9.7 \\
\hline delinquir ("commit crime") & 9.53 \\
\hline aprovechar ("take advantage of") & 9.36 \\
\hline asaltar ("rob") & 9.25 \\
\hline votar ("votar") & 8.98 \\
\hline decir ("say") & 8.89 \\
\hline
\end{tabular}

Table 3. Top ten verb collocates of menas as subject

In the light of the most frequent collocates of menas, it can be said that their use indicates that the speaker maintains derogatory attitudes. Although there are neutral collocates, among the most frequent modifiers and verbs a greater number of pejorative collocates can be observed.

Fifth, offensive variation highlights that, when used offensively, ESTIs do not appear to be equally offensive. In other words, we can rank ESTIs according to a scale of offensiveness. Considering menas collocations, we can say that the term's offensiveness is high. We only must consider collocations such as violadores, "rapist", putos, "fucking", robar, "steal", o apuñalar, "stab", to see the high offensiveness associated with the term. To serve as a contrast, consider the most frequent collocations of an ESTI as portera, "doorwoman". When searched as an i-ESTI in the esTenTen Corpus (Kilgarriff and Renau, 2013) in Sketch Engine, ${ }^{13}$ we only find one negative term among the top 200 most frequent collocations: cotilla, "gossiper" (Log Dice: 4.36). Moreover, since the offensiveness of ESTIs depends on the stereotypes associated with each term, the more negative the stereotypes, the higher the offensiveness. As can be seen, the stereotype of being someone who is a gossiper, someone who cannot keep a secret, is negative, but it is far from being as negative as being a person who rapes, steals, and stabs.

In summary, the combined evidence from the collocation and concordance analysis concludes that menas exhibit four of the five defining characteristics of ESTIs. Regarding mixed embedding behavior, the evidence is not conclusive, as there is no clarity in the intuitions elicited by the examples extracted from the corpus. In the next section, we will discuss some of the reasons why we believe this to be the case. We will also discuss the results to analyse the status of the term and its dynamics and future evolution.

13 We conducted the search on May 27, 2021. 


\section{Discussion}

The results of the analyses presented in the previous section conclude that menas is an ESTI. First, there are key features of ESTIs that seem to fit well with how the term menas is used. On the one hand, there are neutral and offensive uses of the term; on the other hand, their offensiveness depends on the insulted person meeting the stereotypes usually associated with the target group. Besides, as shown by the analyses, menas exhibits four of the five defining features of ESTIs, being mixed embedding behaviour doubtful. The concordance analysis allowed us to show the context-dependent offensiveness of the term. In other words, we find that menas, when used as an i-ESTI, is almost always offensive, and when used as a w-ESTI, there are offensive and neutral cases. Through the concordance analysis, we also proved the stereotype-based offensiveness of the term. We found examples where the application of the term does not depend on the individual belonging to the group but rather the individual meets the negative stereotypes associated with the term.

The collocation analysis allowed us to show both the perspective dependence and the offensive variation of the term. Concerning the former, we found neutral collocates, for example, menores, "minors", niños, "children", o nacer, "to be born", but also a significantly higher number of pejorative collocates, especially concerning modifiers, for example, putos, "fucking", malditos, "damned", violadores, "rapist", and violentos, "violent", and verbs to which menas appears as subject, for example, robar, "steal", saquear, "loot", apuñalar, "stab", delinquir, "commit crime", and asaltar, "rob". Concerning the latter, the analysis allowed us to compare the offensiveness of menas and another ESTI such as portera, "doorwoman", showing that menas is a much more offensive ESTI.

Regarding the last characteristic, mixed embedding behaviour, the corpus evidence is not clear. We believe that the variation in intuitions about the embedding behavior of menas, when used as a w-ESTI, is partly due to the examples being considered out of context. In this way, we believe there will be cases where menas, used as a w-ESTI, projects out when embedded in a question or a denial and others where not. We do not know this with total certainty, but we can assume that an excellent guide to know it will be the collocation and concordance analyses. It is likely not to project if the term is surrounded by neutral terms such as niños, "children", or menores, "minors". However, if negative terms like violentos, "violent", or robar, "steal", accompany the term, it is likely to project even if it is embedded in a question or a negation. Consider the following example of the corpus:

(22) ¿Seguro que no son menas? "Are you sure they are not menas?"

Considered in isolation, the term does not project. The speaker asks a question because $\mathrm{s} / \mathrm{he}$ is not sure, and therefore it cannot be said that $\mathrm{s} / \mathrm{he}$ maintains derogatory attitudes. However, if we consider the example with more context, the intuition changes:

(23) ¿Seguro que no son menas? La España que madruga y se ducha se dedica a construir y producir. Nunca a destruir. "Are you sure they are not menas? The Spain that gets up early and takes a shower is dedicated to building and producing. Never to destroying. 
In sum, it seems that menas projects out when used as an i-ESTI, but more evidence is needed to determine if menas projects out or not when used as a w-ESTI. An exhaustive analysis of the embedding behavior of the term would entail a close reading of the context of each case.

In sum, it appears that the term menas is an ESTI, since it exhibits almost all the features typical of this type of term. However, we believe that the term may be in the process of becoming a slur. In fact, we believe that two scenarios are possible. On the one hand, on the assumption that the pejorative use of menas is relatively recent, it seems clear that the features of the word are not fully defined. Besides, to the extent that there are neutral uses, it may make sense to continue to argue that it is an ESTI. If people who know the origin of the term continue to use it neutrally and fight to prevent the increasing pejorative use of the term, perhaps they can maintain this double use.

On the other hand, the neutral use could be lost over time and menas may become a slur. If, in addition to the people that uses the term pejoratively in a systematic manner, people who know its origin prefer not to use it anymore or to use other expression instead-for example, "unaccompanied foreign minors" (as some associations seem to propose, arguing that menas makes invisible the fact that they are minors) - , then menas may remain exclusively a slur.

Therefore, it seems that we are in a halfway point in which both things are possible. How the term evolves will depend on how speakers use it from now on. What is clear is that there are two tendencies of usage that are in tension with each other. Several examples in the corpus show that the debate on the application of the term is already underway. Consider the following examples:

(24) Vosotros sois más de llamar MENAS a cualquiera que haga un delito sin saber su procedencia y si nacieron aquí o están con sus padres. "You just call MENAS anyone who commits a crime without knowing where they come from and whether they were born here or are with their parents."

(25) Y por último, llamar MENAS a chicos que no sabemos si quiera si son españoles o tienen familia solo para criminalizar un colectivo es ser basura. "Finally, calling MENAS kids that we don't even know if are Spanish or have a family just to criminalize a collective is being trash."

Besides, the analyses allow us to get some general clues about how to pave the way to hell, that is, the process of conversion of a neutral word into a pejorative one. In particular, the systematic appearance of an expression, initially neutral, together with explicitly pejorative expressions is at least one of the mechanisms through which a descriptive expression ends up acquiring an expressive meaning. This expressive meaning may coexist with the descriptive meaning, turning a descriptive term into an ESTI, or it may end up phagocytizing the descriptive meaning altogether, becoming a slur. What happens depends on what speakers do. For example, in the case of the expression under consideration, there is a perceived tendency not to use the expression by those who consider that the expression has acquired a pejorative meaning. If they cease to use it in a neutral way, the word will become part of the dialect of racists and become a slur. If they struggle to maintain the neutral use of the term, the word will remain an ESTI. 


\section{Conclusion}

In this paper, we have explored the status of the term menas, a term that has attracted considerable attention in Spanish politics in the last few years. The main aim was to determine if menas is an ESTI or rather a slur. First, we defined both kinds of terms, presenting their most defining characteristics. Second, we compiled a corpus consisting of tweets involving the term. Third, we ran two different types of analysis, a collocation and a concordance analysis, to determine the status of the term. The results of the analyses show that menas exhibits the most defining characteristics of ESTIs. However, it seems that neutral uses of the term are on the decline. The corpus yields evidence in this sense since, for example, the term co-occurs more frequently with pejorative terms than with neutral ones, as the collocation analysis shows. For this reason, we believe that the term, currently, is in the process of becoming a slur. To account for this possible dynamic, we have pointed out two possible scenarios. On the one hand, the term could maintain its neutral uses and thus continue to be an ESTI. However, it is also possible that the neutral uses disappear over time, and only the pejorative ones remain. If this were to happen, the term would become a slur.

\section{References}

Anderson, L. \& Lepore, E. (2013), "Slurring words", Noûs, 47(1), pp. 25-48.

Baker, P. (2006), Using Corpora in Discourse Analysis, New York: Continuum.

Baker P., Gabrielatos C. \& McEnery T. (2013), Discourse Analysis and Media Studies: The Representation of Islam in the British Press, Cambridge: Cambridge University Press.

Biber et al. (1999), Grammar of Spoken and Written English Language, London: Longman.

Blakemore, D. (2015), "Slurs and expletives: A case against a general account of expressive meaning", Language Sciences, 52, 22-35.

Bluhm, R. (2013), "Don't ask, look! Linguistic corpora as a tool for conceptual analysis", in M. Hoeltje, T. Spitzley, and W. Spohn (eds.): Was dürfen wir glauben? Was sollen wir tun? Sektionsbeiträge des achten internationalen Kongresses der Gesellschaft für Analytische Philosophie, e.V. Duisburg-Essen: DuEPublico, pp. 7-15.

Bluhm, R. (2016), "Corpus analysis in philosophy", in M. Hinton (ed.), Evidence, Experiment and Argument in Linguistics and Philosophy of Language, Oxford: Peter Lang, pp. 91-109.

Bolinger, R. J. (2017), “The pragmatics of slurs”, Noûs, 51(3), 439-462.

Bowker, L. \& Pearson, J. (2002), Working with Specialised Language: A Practical Guide to Using Corpora, London: Routledge.

Camp, E. (2013), "Slurring perspectives”, Analytic Philosophy, 54(3), 330-349.

Castroviejo, E., Fraser, K. \& Vicente, A. (2020), "More on pejorative language: Insults that go beyond their extension", Synthese, DOI: 10.1007/s11229-020-02624-0.

Caton, J. N. (2020), "Using linguistic corpora as a philosophical tool", Metaphilosophy, $51(1), 51-70$.

Cepollaro, B. (2015), "In defense of a presuppositional account of slurs", Language Sciences, 52, 36-45. 
Croom, A. M. (2013), "How to do things with slurs: Studies in the way of derogatory words", Language and Communication, 33(3), 177-204.

Croom, A. M. (2015), "The semantics of slurs: A refutation of coreferentialism". Ampersand, $2,30-38$.

Desagulier G. (2017), Corpus Linguistics and Statistics with R: Introduction to Quantitative Methods in Linguistics, Cham: Springer.

Falbo, A. (2021), "Slurs, neutral counterparts, and what you could have said", Analytic Philosophy, DOI: 10.1111/phib.12217.

Gablasova, D., Brezina, V. \& McEnery, T. (2017), "Collocations in corpus-based language learning research: Identifying, comparing, and interpreting the evidence", Language Learning, 67(S1), 155-179.

Gries S. T. (2017), Quantitative Corpus Linguistics with R: A Practical Introduction, London: Routledge.

Hansen, N. \& Chemla, E. (2015), "Linguistic experiments and ordinary language philosophy", Ratio, 28(4), 422-445.

Hansen, N. (2015), "Experimental philosophy of language", Oxford Handbooks Online, DOI: $10.1093 /$ oxfordhb/9780199935314.013.53.

Hansen et al. (2019), "A corpus study of "know": On the verification of philosophers' frequency claims about language", Episteme, 18(2), 242-268.

Hinton M. (2020), "Corpus linguistics methods in the study of (meta)argumentation", Argumentation, DOI: 10.1007/s10503-020-09533-z.

Hom, C. (2008), "The semantics of racial epithets", The Journal of Philosophy 105(8), $416-440$.

Hunston S. (2002), Corpora in Applied Linguistics, Cambridge: Cambridge University Press.

Jeshion, R. (2013), "Slurs and stereotypes", Analytic Philosophy, 54(3), 314-329.

Kilgarriff, A. \& Renau, I. (2013), "esTenTen, a vast web corpus of Peninsular and American Spanish", Procedia: Social and Behavioral Sciences, 95, 12-19.

McEnery T., \& Hardie A. (2012), Corpus Linguistics: Method, Theory and Practice, Cambridge: Cambridge University Press.

Nunberg, G. (2018), “The social life of slurs”, in D. Fogal, D. Harris \& M. Moss (eds.), New Work on Speech Acts, Oxford: Oxford University Press, pp. 237-295.

Pearson, J. (1998), Terms in Context, Philadelphia: John Benjamins Publishing Company.

Popa-Wyatt, M. \& Wyatt, J. L. (2018), "Slurs, roles and power", Philosophical Studies, 175(11), 2879-2906.

Tallant, J. \& Andow, J. (2020), "English language and philosophy", in S. Adolphs \& D. Knight (eds.), The Routledge Handbook of English Language and Digital Humanities, London: Routledge, pp. 440-455.

Tirrell, L. (1999), "Racism, sexism, and the inferential role theory of meaning", in C. Hendricks \& K. Oliver (eds.), Language and Liberation: Feminism, Philosophy, and Language, New York: State University of New York Press, pp. 41-79.

Zeman, D. (2021), "A rich-lexicon theory of slurs and their uses", Inquiry, DOI: 10.1080/0020174X.2021.1903552. 